\title{
China: Threat or Opportunity?
}

\begin{abstract}
China today is the superpower with the greatest "spiritual vitality". While many in the United States see this as a threat to its primacy, the United States should instead work with China to better the lives of its people.
\end{abstract}

Is China a threat or an opportunity for America?

Is that a simple question? As a student of philosophy, I have learned that behind a simple question can lurk many others that are more complex. Here are a few for that particular question: Does China intend to weaken or undermine America? Or is its rise driven by domestic factors? Does China have a grand strategy? If so, what are its primary goals? Is China's rise a threat to American primacy or to the American people? And, perhaps most controversially, should America give priority to geopolitical primacy or to its citizens in taking on the challenge from China?

Curiously, there has been little genuine debate on this complex challenge in the US Instead, there has been a dramatic convergence in the opinions of many Americans, despite deep political polarization, toward the view that China is a threat. Nine in ten Americans believe that, according to a recent Pew poll. The "deep state" has also turned against China. As Henry Paulson put it last year: "You have Homeland Security, the FBI, CIA, the Defense Department, treating China as the enemy and members of Congress competing to see who can be the most belligerent China hawk. No one is leaning against the wind, providing balance."

The goal of this essay is to provide some balance and objectivity.

Despite this extraordinary convergence of views, most thoughtful Americans would agree that China has no plan to invade or occupy America. It would be a mission impossible. Nor would China dream of launching a nuclear attack. It has only about 290 nuclear weapons, compared to America's 6000-plus. Nor does China have any desire to close off sea lanes, like Germany tried to do in World War II. China does more international trade than America. Paradoxically, the US Navy is keeping sea lanes open for Chinese commerce.

Yet, it is also true that there has been a significant change in military balance between China and America. In 1996, President Bill Clinton sent two aircraft carriers

Originally published in Noema, Jun 15, 2020 
to patrol the ocean off the coast of China to dissuade Beijing from being too aggressive toward Taiwan. Today, these two aircraft carriers would be sitting ducks in the face of Chinese hypersonic missiles. The military balance has shifted, creating discomfort in Washington.

Even so, this isn't where the primary challenge will arise from China. In the era of nuclear weapons, superpower primacy is likely to be determined in the economic sphere, not military sphere.

One of America's wisest strategic thinkers was the diplomat George Kennan, who lived from 1904 to 2005. When America embarked on its great geopolitical contest against the Soviet Union, Kennan said the final outcome would be determined by "the degree to which the United States can create among the peoples of the world generally the impression of a country which knows what it wants, which is coping successfully with the problem of its internal life and with the responsibilities of a world power, and which has a spiritual vitality capable of holding its own among the major ideological currents of the time".

Kennan added that with this "spiritual vitality," America should cultivate more "friends and allies." He also counseled "humility" and bravely said America should avoid "insulting" the Soviet Union, as America would still have to deal with it.

Fortunately, Kennan's strategic advice was largely heeded. America won the geopolitical contest against the Soviet Union handsomely. Curiously, even though China will be a far more formidable superpower rival, with four times the population of America and a political resilience that is at least 4000 years old, America has not attempted to work out a comprehensive long-term strategy to deal with it.

If Kennan is right and the contest will be determined by domestic "spiritual vitality," China is winning. America is the only major developed society where the real wages for the bottom half of the working population declined over a 30year period. In turn, this has generated a "sea of despair" among the white working classes, as documented by Princeton economists Anne Case and Angus Deaton.

By contrast, 1.4 billion Chinese people have experienced an extraordinary improvement in living standards. The past 40 years have been the best the Chinese have experienced in 4000 years. As a result, as the researcher, Jean Fan has documented: "In contrast to America's stagnation, China's culture, self-concept, and morale are being transformed at a rapid pace-mostly for the better." China has spiritual vitality. America, not as much.

If Kennan were alive today, he would be deeply alarmed. He would strongly argue against burning money in useless foreign interventions. In fact, he was alive when the Iraq War began in 2003 — and he opposed it. If America had heeded his advice and disbursed the roughly USD 5.4 trillion it spent on post-9/11 wars in the Middle East and Central Asia on its own people instead, each member of the bottom 50\% of the population would have received a check for more than USD 33,000. This is why Eisenhower wisely advised in 1953 that "every gun that is made, every warship launched, every rocket fired signifies, in the final sense, a theft from those who hunger and are not fed, those who are cold and are not clothed".

America is still a much richer country than China, with a per capita income of around USD 63,000 compared to USD 9700 for China. Its universities and scientific 
expertise are clearly superior to China's. Yet when Covid-19 hit, China experienced 0.33 deaths per 100,000 people (as of mid-May). The US figure was 27. One figure cannot tell everything. But it provides a clue that China has been investing in strong domestic institutions, especially in public service, while America has been neglecting them. President Ronald Reagan began this slide when he declared: "Government is not the solution to our problem; it is the problem." China believes otherwise.

All this brings up the key dilemma America faces in taking on the strategic challenge from China: Should it focus on defending American primacy or defending the well-being of its people? Most Americans assume that America is rich and powerful enough to do both. Sadly, the data argue otherwise. As the Nobel Laureate Joseph Stiglitz and Harvard professor Linda Bilmes have said regarding the money spent on Iraq: " $[\mathrm{H}] \mathrm{ad}$ the taxpayer's taxes been reduced commensurately, or if the money had been spent on providing healthcare, it would have made a difference to hard-pressed middle-class families." With better healthcare, fewer Americans would have died from Covid-19. The price for giving strategic priority to American primacy has been paid by the American people.

Can America change direction and focus on domestic economic and social development instead of wasteful external adventures? In theory, yes. In practice, it will be difficult. America has had many brilliant defense secretaries. None could reduce defense department expenses. Why not? Defense spending results from a complex lobbying system rather than from a comprehensive rational strategy.

Nevertheless, it remains true that there is a strong consensus within the American body politic, especially among the American elite, that America should remain number one. Americans feel an obligation to lead the world. Secretary of State Madeleine Albright expressed this well in 1998: "If we have to use force, it is because we are America; we are the indispensable nation. We stand tall, and we see further than other countries into the future, and we see the danger here to all of us." Americans want America to be the "shining city on a hill," inspiring the rest of the world.

Indeed, the rest of the world would be happy to see a strong, self-confident America inspiring us all. However, its "shine" comes from its domestic record, not its military adventures. Clearly, the "sea of despair" among the working classes, the rise of populism, the election of Donald Trump and the recent incompetency around Covid19 have dented America's standing in the world. Any empirical study would show that while America's geopolitical influence has been receding, China's has been gradually expanding.

But even if China's influence has grown, it has no desire to step into America's shoes and provide global leadership. China has only one key strategic goal: to become strong enough to prevent another century of humiliation, the period between 1842 and 1949 when Western forces trampled on China with great abandon. China regained its strength by plugging into the rules-based global order that America gifted to the world in 1945.

China has no desire to overturn this order. It would be happy to cooperate with America within it. In short, a prosperous China can live together in peace with 
a prosperous America, as inconceivable as this thought might seem in the toxic political environment in the US.

Hence, at the end of the day, all is not lost for America. It can reverse its slide in geopolitical fortunes. However, to do so, it must begin to heed the advice of its strategic thinkers, like Kennan. As Kennan said, it should become humble and stop insulting adversaries. It should cultivate friends and allies and focus on its domestic spiritual vitality. Even to a lay observer, this is plain common sense. America can still win-not by investing in military supremacy but in moral supremacy. Until it does that, it is ceding the playing field to China.

Open Access This chapter is licensed under the terms of the Creative Commons AttributionNonCommercial-NoDerivatives 4.0 International License (http://creativecommons.org/licenses/bync-nd/4.0/), which permits any noncommercial use, sharing, distribution and reproduction in any medium or format, as long as you give appropriate credit to the original author(s) and the source, provide a link to the Creative Commons license and indicate if you modified the licensed material. You do not have permission under this license to share adapted material derived from this chapter or parts of it.

The images or other third party material in this chapter are included in the chapter's Creative Commons license, unless indicated otherwise in a credit line to the material. If material is not included in the chapter's Creative Commons license and your intended use is not permitted by statutory regulation or exceeds the permitted use, you will need to obtain permission directly from the copyright holder.

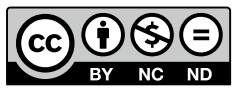

